\title{
Relationship between exhaled nitric oxide and airway hyperresponsiveness following experimental rhinovirus infection in asthmatic subjects
}

\author{
H.W.F.M. de Gouw*, K. Grünberg*, R. Schot*, A.C.M. Kroes**, E.C. Dick+, P.J. Sterk*
}

Relationship between exhaled nitric oxide and airway hyperresponsiveness following experimental rhinovirus infection in asthmatic subjects. H.W.F.M. de Gouw, K. Grünberg, R. Schot, A.C.M. Kroes, E.C. Dick, P.J. Sterk. (CERS Journals Ltd 1998.

ABSTRACT: Exhaled nitric oxide (NO) is elevated in asthmatics, and varies with disease severity. We postulated that a respiratory virus infection increases exhaled NO levels in asthma, and examined the relationship between the virus-induced changes in exhaled NO and in airway hyperresponsiveness to histamine.

In a parallel study, seven patients underwent experimental rhinovirus 16 (RV16) inoculation at days 0 and 1, whilst seven patients received placebo. Exhaled NO was measured at baseline (day 0 ) and at days 1,2 and 3 after inoculation. Histamine challenges were performed prior to (day -7) and after inoculation (day 3), and were expressed as provocative concentration causing a $20 \%$ fall in forced expiratory volume in one second (FEV1) (PC20).

Following RV16 infection there was a significant increase in NO at days 2 and 3 as compared to baseline (median change (range): 4.2 (7.5) parts per billion (ppb), $\mathrm{p}=0.03$, and 3.0 (10.1) $\mathrm{ppb}, \mathrm{p}=0.02$, respectively). Furthermore, $\mathrm{PC} 20$ decreased significantly following RV16 infection (mean \pm SD change in doubling dose: $\mathbf{- 0 . 6 5 \pm 0 . 5 4}$, $p=0.02$, whereas $\mathbf{P C 2 0}$ did not change in the placebo group $(p=0.1)$. There was a significant correlation between the RV16-induced changes in exhaled NO levels at day 2 and the accompanying changes in $\mathrm{PC} 20$ at day 3 (rank correlation coefficient $\left(\mathbf{r}_{\mathrm{s}}\right)$ : $0.86, p=0.01$ ). Hence, the greater the increase in exhaled NO, the smaller the decrease in $\mathrm{PC20}$.

We conclude that rhinovirus infection increases exhaled nitric oxide levels in asthmatics, and that this increase is inversely associated with worsening of airway hyperresponsiveness to histamine. These results suggest that viral induction of nitric oxide synthase within the airways may play a protective role in exacerbations of asthma. Eur Respir J 1998; 11: 126-132.
Depts of *Pulmonology and **Virology, Leiden University Medical Centre, Leiden, The Netherlands. ${ }^{+}$Dept of Preventive Medicine, University of Wisconsin, Madison, WI, USA.

Correspondence: H.W.F.M. de Gouw

Lung Function Laboratory C2-P

P.O. Box 9600

NL-2300 RC Leiden

The Netherlands

Fax: 0031715154691

\section{Keywords: Asthma}

bronchial hyperreactivity

nitric oxide

rhinovirus

Received: December 301996

Accepted after revision September 111997
Asthma is a chronic inflammatory disease of the airways characterized by episodic chest tightness, wheezing, and variable bronchoconstriction associated with an increased airway hyperresponsiveness to various nonsensitizing stimuli $[1,2]$. Recently, it has been suggested that nitric oxide (NO) is involved in the pathophysiology of airway disease such as asthma [3,4]. Endogenous NO is detectable in exhaled air of normal individuals $[5,6]$, and appears to be increased in patients with asthma [7-9], which is most likely due to elevated NO production in the intrapulmonary airways [10]. Recently, it has been demonstrated that exhaled NO varies with disease severity in asthma, as occurs during exacerbations [11] and after adequate treatment $[11,12]$.

$\mathrm{NO}$ is generated from the guanidino nitrogen of L-arginine during the oxidation to L-citrulline by the enzyme NO synthase (NOS), of which constitutive (cNOS) and inducible (iNOS) isoforms have been described [13]. Constitutive NOS, basically expressed in endothelial and neuronal cells, releases only small amounts of NO within seconds in response to increases in intracellular calcium [13]. On the other hand, expression of iNOS in epithelial and several inflammatory cells can be induced by pro- inflammatory cytokines such as tumour necrosis factor- $\alpha$ (TNF- $\alpha$ ), interleukin (IL)-1 $\beta$, and interferon (IFN- $\gamma$ ) [14], resulting in relatively high levels of NO. There is increasing evidence that NO production within the airways can have divergent effects. The relatively low concentrations generated by cNOS activity can lead to airway and vascular smooth muscle relaxation, whereas iNOS activity may limit cNOS activity, whilst having pro-inflammatory, immunomodulatory [15], and antiviral effects [16].

Virus infections are closely associated in time with asthma exacerbations $[17,18]$, leading to a flare-up in symptoms, a transient increase in airway hyperresponsiveness to methacholine [19] or histamine [20, 21], and an increased production of proinflammatory cytokines within the airways [22-24]. It can therefore be postulated that NO production increases during viral respiratory tract infection. Indeed, KHARITONov et al. [25] have reported that exhaled NO levels were increased in normal subjects during naturally acquired upper respiratory tract infections, 
presumably from viral origin. However, even though NO may exert several proinflammatory effects within the airways [15], recent studies have suggested a potentially protective role of NO in virus-induced airway hyperresponsiveness in guinea-pigs [26]. However, it is still unknown whether NO production has a pathophysiological role in viral respiratory tract infections in patients with asthma.

In the present study, we hypothesized that exhaled NO will increase following rhinovirus 16 (RV16) infection in asthmatic subjects in vivo. To that end, exhaled NO levels were documented before and after experimental RV16 infection or placebo in asthmatic subjects in vivo. As a second objective, we examined the relationship between RV16-induced changes in exhaled NO and those in lung function and airway hyperresponsiveness to histamine.

\section{Materials and methods}

\section{Subjects}

Fourteen nonsmoking, atopic, asthmatic volunteers participated in this study (table 1). The subjects included in the RV16 group $(n=7)$ had no serum neutralizing antibodies to RV16 (antibody titre $\leq 2$ ). All had mild to moderate persistent asthma, and symptoms were controlled by on demand usage of inhaled, short-acting $\beta_{2}$-agonists alone. Their atopic status was confirmed by a positive skin-prick test to at least one of 16 common airborne allergen extracts (wheal $\geq 3 \mathrm{~mm}$; Vivodiagnost, ALK, Benelux). Their baseline forced expiratory volume in one second (FEV1) was $\geq 70 \%$ of predicted (range: $72-102 \%$ pred) [27], and all were hyperresponsive to inhaled histamine (provocative concentration causing a $20 \%$ fall in FEV1 (PC20) range: $0.15-4 \mathrm{mg} \cdot \mathrm{mL}^{-1}$ ) [28]. There was no history of up-per respiratory tract infection or relevant allergen exposure during 2 weeks prior to the study. The subjects had not used corticosteroids, antihistamines, sodium cromoglycate, nedocromil sodium or theophyllines for at least 3 months prior to the study. Before testing, the subjects were asked to refrain from inhaled short-acting broncho-dilators and caffeine-containing beverages for at least $8 \mathrm{~h}$ and $4 \mathrm{~h}$, respectively. The protocol was approved by the Medical Ethics Committee of the Leiden University Hospital, and all participants gave their informed consent.

\section{Study design}

On screening days prior to the study, the inclusion criteria were examined for each subject. The study had a placebo-controlled, parallel design and was performed in the winter season. On the first study visit (day -7), a histamine challenge was performed. Subsequently, RV16 or placebo was inoculated at days 0 and 1 . NO was measured before inoculation (day 0, baseline) and at days 1, 2, and 3. Histamine challenge was repeated subsequent to the NO measurement at day 3. In order to confirm viral infection, nasal washings for viral culture were taken immediately before virus or placebo inoculation at day 0 and subsequently on day 2. Furthermore, blood samples were taken at the first study visit and 3 weeks after the inoculation for determination of RV16 neutralizing antibody titre. NO measurements and histamine challenges were performed at the same time of day $( \pm 2 \mathrm{~h})$ in each subject.

\section{RV16 inoculation and laboratory confirmation of infec-} tion

The RV16 strain and stock was the same as used in previous experiments in humans in vivo by others [29] and by ourselves $[19,21]$. The virus was cultured according to standards of good laboratory practice and the inoculum

Table 1. - Subject characteristics

\begin{tabular}{|c|c|c|c|c|c|c|c|c|}
\hline \multirow{2}{*}{$\begin{array}{l}\text { Patient } \\
\text { No. }\end{array}$} & \multirow[t]{2}{*}{ Sex } & \multirow{2}{*}{$\begin{array}{l}\text { Age } \\
\text { yrs }\end{array}$} & \multirow{2}{*}{$\begin{array}{c}\text { FEV1 } \\
\text { \%pred* }\end{array}$} & \multirow{2}{*}{$\begin{array}{c}\mathrm{PC} 20 \\
\text { histamine } \\
\mathrm{mg} \cdot \mathrm{mL}^{-1 *}\end{array}$} & \multirow{2}{*}{$\begin{array}{l}\text { Viral culture } \\
\quad \text { day } 2\end{array}$} & \multicolumn{2}{|c|}{ RV16 $_{\text {titre }}^{\dagger}$} & \multirow[t]{2}{*}{ Atopy } \\
\hline & & & & & & Pre & Post & \\
\hline \multicolumn{9}{|l|}{ Placebo } \\
\hline 1 & $\mathrm{~F}$ & 20 & 90.8 & 0.16 & Negative & 2 & 2 & $\mathrm{H}, \mathrm{C}$ \\
\hline 2 & $\mathrm{~F}$ & 21 & 90.7 & 0.27 & Negative & 16 & 16 & $\mathrm{H}, \mathrm{C}$ \\
\hline 3 & $\mathrm{M}$ & 22 & 102.0 & 0.27 & Negative & 4 & 4 & $\mathrm{H}, \mathrm{P}$ \\
\hline 4 & $\mathrm{~F}$ & 24 & 86.9 & 0.32 & Negative & 32 & 16 & $\mathrm{P}, \mathrm{C}$ \\
\hline 5 & $\mathrm{~F}$ & 23 & 85.9 & 0.59 & Negative & 256 & 256 & $\mathrm{H}, \mathrm{C}$ \\
\hline 6 & $\mathrm{~F}$ & 21 & 86.2 & 0.67 & Negative & 16 & 16 & $\mathrm{H}, \mathrm{P}, \mathrm{C}$ \\
\hline 7 & M & 21 & 102.0 & 1.33 & Negative & 8 & 16 & $\mathrm{H}$ \\
\hline Mean \pm SEM & & & $92.1 \pm 2.7$ & $0.41 \pm 1.02 \mathbb{I}$ & & & & \\
\hline \multicolumn{9}{|l|}{ RV16 } \\
\hline 8 & M & 26 & 73.5 & 0.15 & RV16 & 1 & 16 & $\mathrm{H}$ \\
\hline 9 & $\mathrm{~F}$ & 22 & 86.3 & 0.22 & RV16 & 1 & 4 & $\mathrm{H}, \mathrm{P}, \mathrm{C}$ \\
\hline 10 & M & 20 & 98.0 & 0.62 & RV16 & 2 & 16 & $\mathrm{H}$ \\
\hline 11 & $\mathrm{M}$ & 25 & 71.5 & 0.80 & RV16 & 1 & 8 & $\mathrm{H}$ \\
\hline 12 & M & 20 & 94.3 & 1.08 & RV16 & 1 & 128 & $\mathrm{P}, \mathrm{C}$ \\
\hline 13 & M & 25 & 96.0 & 2.98 & RV16 & 1 & 2 & $\mathrm{C}$ \\
\hline 14 & $\mathrm{~F}$ & 24 & 89.8 & 4.00 & Negative & 2 & 32 & $\mathrm{H}, \mathrm{P}, \mathrm{C}$ \\
\hline Mean \pm SEM & & & $87.1 \pm 4.0$ & $0.80 \pm 1.76^{\mathbb{I}}$ & & & & \\
\hline
\end{tabular}

M: male; F: female; FEV1: forced expiratory volume in one second; PC20: provocative concentration causing a 20\% fall in FEV1; RV16: rhinovirus 16; H: house dust mite; C: cat; P: pollen. *: measured at entry of the study; ${ }^{\dagger}$ neutralizing antibody titre in serum dilution against 25 median tissue culture infective doses of RV16 (post: 3 weeks after infection); ${ }^{\ddagger}$ : atopy determined by skin-prick test (Vivodiagnost, ALK, Benelux); II: geometric mean \pm SD in doubling dose. NB Subject No. 14 had a negative viral culture, but a greater than fourfold increase in RV16 neutralizing serum antibodies. 
was tested to be safe for human in vivo usage [30]. Nasal inoculation was performed according to a previously described protocol [19]. In short, RV16 (1.3-2.8 $\times 10^{4}$ $50 \%$ tissue culture infective dose (TCID50)) or placebo was nasally administered by inhalation (pressurized DeVilbiss 646 nebulizer with face-mask; DeVilbiss Co., Somerset, PA, USA), spraying (compressor-driven DeVilbiss 286 atomizer), and instillation of droplets (by pipette) into each nostril $[19,21]$.

RV16 infection was confirmed by a fourfold or greater increase in RV16 neutralizing antibodies in serum and/or recovery of RV16 from nasal washings [19, 21].

\section{NO measurements}

Exhaled NO measurements were performed according to a reproducible method (intraclass correlation coefficient in nine mildly to moderately asthmatic subjects in our laboratory being 0.81 (unpublished data)) using a chemiluminescence analyser (Sievers NOA 270B, Sievers, Boulder, CO, USA). The subjects were asked to produce a slow expiratory vital capacity manoeuvre with a constant expiratory flow of 0.05 times the forced expiratory volume $(\mathrm{FVC})$ per second $\left(0.05 \times \mathrm{FVC} \cdot \mathrm{s}^{-1}\right)$ into a $26 \mathrm{~mm}$ Teflon cylinder connected to $3 \mathrm{~mm}$ Teflon tubing, with the nose clipped. Expiratory flow rates ranged 10.220.0 L. $\mathrm{min}^{-1}$ between subjects. Expired NO was sampled continuously from the centre of the flow with a sample flow of $440 \mathrm{~mL} \cdot \mathrm{min}^{-1}$. The expiratory flow was measured by a pneumotachograph (Lilly principle, Erich Jaeger Gmbh, Würzburg, Germany). Exhaled NO concentrations were determined at the plateau between 5-15 s after the start of the expiration and expressed as parts per billion (ppb). NO concentrations were calibrated using a calibration line of $\mathrm{NaNO}_{2}$ (Merck, Darmstadt, Germany) in physiologic saline $(0.9 \% \mathrm{NaCl})$ as a reference. Three successive recordings at 2 min intervals were made and the mean was used in analysis.

\section{Histamine challenge}

Standardized histamine challenge tests were performed using histamine biphosphate (Sigma chemicals, Bufa, Uitgeest, The Netherlands) in phosphate-buffered saline [28]. Serial doubling concentrations ranging $0.03-8 \mathrm{mg} \cdot \mathrm{mL}^{-1}$ were aerosolized using a DeVilbiss 646 nebulizer (DeVilbiss Co., Somerset, PA, USA) (output $0.13 \mathrm{~mL} \cdot \mathrm{min}^{-1}$ ) which is connected to the central chamber of an inspiratory and expiratory valve box with an expiratory aerosol filter (Pall Ultipor BB50T; Pall Biomedical Products Co., East Hills, NY, USA). The aerosols were inhaled by tidal breathing for $2 \mathrm{~min}$ at 5-min intervals, with the nose clipped.

The response to histamine was recorded by FEV1 using a dry-rolling seal spirometer (Morgan Spiroflow, Rainham, UK) before the test and at $45 \mathrm{~s}$ after each inhalation. Baseline FEV1 was determined as the mean of three reproducible values (FEV1 within 5\%). The test was discontinued when a $20 \%$ fall in FEV1 from baseline was reached, after which $200 \mu \mathrm{g}$ salbutamol was inhaled to provide adequate bronchodilation. The response to histamine was measured as PC20.
Analysis

PC20 was log-transformed before statistical analysis in order to obtain normal data distribution, and expressed as geometric mean \pm SD in doubling dose (DD). Changes in $\mathrm{PC}_{20}$ were expressed in DD. The difference in $\mathrm{PC} 20$ preversus postinoculation within each treatment group was tested using Student's paired t-test, whereas the differences in levels and in changes in PC20 histamine between both groups were tested using Student's unpaired t-test. Exhaled NO values below half the detection limit, which according to the manufacturer is $<1 \mathrm{ppb}$, were censored by taking half the detection limit, e.g. $0.5 \mathrm{ppb}$. Since exhaled NO levels ( $\mathrm{ppb}$ ) were not normally distributed, exhaled NO levels and their changes were analysed nonparametrically and expressed as median and corresponding range.

To test for the differences between treatments in general, multivariate analysis of variance (MANOVA) was applied on the actual data with virus or placebo as a between-group factor. Additionally, Wilcoxon signed-rank test was used to explore significant MANOVA effects for each time-point as compared to baseline within each treatment group. The Mann-Whitney rank-sum test was applied to test for differences between both treatment groups in exhaled NO values at baseline and for differences between the groups in changes in exhaled NO levels at all time-points as compared to the baseline values. Finally, Spearman rank correlation analysis was used to examine the relationship between baseline exhaled NO and baseline PC20 histamine and FEV1 \% pred, and furthermore between changes in exhaled NO levels and changes in airway hyperresponsiveness to histamine. A p-value less than 0.05 was considered statistically significant.

\section{Results}

\section{Virus confirmation}

RV16 infection was confirmed in all RV16-treated subjects either by a greater than fourfold increase in RV16 neutralizing antibodies in serum and/or recovery of RV16 from nasal washings. Cultures of the nasal washings were negative in all of the placebo-inoculated subjects (table 1).

\section{Baseline lung function}

Before RV16 or placebo inoculation, baseline FEV1 (\% pred) was not different between the treatment groups (mean \pm SEM: $87.1 \pm 4.0$ (RV16 group) versus $92.1 \pm 2.7 \%$ pred (placebo group), $\mathrm{p}=0.3$ ). During the study there were no significant changes in FEV1 in either treatment group $(p>0.2)$, nor was there a significant difference in the changes in FEV1 between both groups $(\mathrm{p}=0.6)$.

\section{Histamine challenge}

PC20 to histamine was not different between the two treatment groups prior to the inoculation $($ day -7$)(p=0.2)$ 
(table 2). A significant decrease in $\mathrm{PC} 20$ to histamine was observed in the RV16-infected group (mean change ( \pm SD) in DD: $-0.65 \pm 0.54, \mathrm{p}=0.02$ ) at day 3 as compared to the baseline value, whereas no significant difference could be found in the placebo group $(0.30 \pm 0.43, p=0.1)$. These changes in $\mathrm{PC} 20$ were significantly different between the two treatment groups $(\mathrm{p}=0.003)$.

\section{NO measurements}

Individual exhaled NO levels are presented in table 3. At day 1, exhaled NO levels could not be determined in subject No. 8 (missing value, due to a technical problem). There was a trend towards a difference in baseline exhaled NO levels between both treatment groups which did not reach statistical significance $(\mathrm{p}=0.06)$. Exhaled NO increased significantly in the RV16-treated group as compared to placebo in time (MANOVA, $p=0.04$ ). In the RV16 group there was a significant increase in exhaled

Table 2. - Effect of RV16 infection on airway hyperresponsiveness to histamine

\begin{tabular}{lccccc}
\hline & \multicolumn{2}{c}{ PC20 histamine } & & \multicolumn{2}{c}{$\mathrm{p}$-value } \\
\cline { 2 - 3 } \cline { 5 - 6 } & Pre & Post & & Pre-Post & $\Delta^{*}$ \\
\hline RV16 & $0.80 \pm 1.76$ & $0.51 \pm 1.63$ & & 0.02 & \multirow{2}{*}{0.003} \\
Placebo & $0.41 \pm 1.02$ & $0.51 \pm 1.04$ & & 0.12 & 0 \\
p-value & 0.2 & 0.9 & & & \\
\hline
\end{tabular}

$\mathrm{PC} 20$ histamine values are presented as geometric mean $\pm \mathrm{SD}$ in doubling doses. *: the difference in changes in $\mathrm{PC} 20$ histamine between the two measurements (unpaired t-test). PC20: provocative concentration causing a $20 \%$ fall in forced expiratory volume in one second; RV16: rhinovirus 16.

Table 3. - Individual exhaled NO levels on each study day

\begin{tabular}{|c|c|c|c|c|}
\hline \multirow{2}{*}{$\begin{array}{c}\text { Patient } \\
\text { No. }\end{array}$} & \multicolumn{4}{|c|}{ Exhaled NO levels ppb } \\
\hline & Day 0 & Day 1 & Day 2 & Day 3 \\
\hline \multicolumn{5}{|l|}{$\overline{\text { Placebo }}$} \\
\hline 1 & 10.4 & 7.7 & 9.3 & 7.8 \\
\hline 2 & 12.1 & 12.1 & 11.5 & 9.4 \\
\hline 3 & 6.7 & 18.3 & 8.1 & 3.1 \\
\hline 4 & 19.3 & 12.7 & 11.3 & 18.2 \\
\hline 5 & 11.4 & 12.1 & 11.6 & 14.4 \\
\hline 6 & 2.8 & 4.2 & 3.2 & 4.8 \\
\hline 7 & 3.1 & 5.0 & 2.8 & 2.4 \\
\hline Median & 10.4 & 12.0 & 9.3 & 7.8 \\
\hline (range) & $(16.5)$ & $(14.1)$ & (8.8) & (15.9) \\
\hline \multicolumn{5}{|l|}{ RV16 } \\
\hline 8 & 1.9 & MV & 8.5 & 6.2 \\
\hline 9 & 18.3 & 20.7 & 23.1 & 29.1 \\
\hline 10 & 5.7 & 4.2 & 7.7 & 6.7 \\
\hline 11 & 0.5 & 1.2 & 4.7 & 4.4 \\
\hline 12 & 5.6 & 7.3 & 12.9 & 8.6 \\
\hline 13 & 0.9 & 0.5 & 0.8 & 2.8 \\
\hline 14 & 1.4 & 4.3 & 2.3 & 2.2 \\
\hline Median & 1.9 & 4.2 & 7.7 & 6.2 \\
\hline (range) & $(17.8)$ & (20.2) & $(22.3)^{*}$ & $(26.9)^{*}$ \\
\hline p-value ${ }^{\dagger}$ & $0.06+$ & 0.5 & 0.01 & 0.02 \\
\hline \multicolumn{5}{|c|}{$\begin{array}{l}\text { MV: missing value; } *: p<0.05 \text {, change in exhaled NO levels as } \\
\text { compared to baseline (day } 0) ;: \text {-values of differences in the } \\
\text { changes of exhaled NO levels from baseline between the RV16 } \\
\text { and placebo group; } ¥ \text { - p-value of the difference between exhaled } \\
\text { NO levels at baseline between both treatment groups. }\end{array}$} \\
\hline
\end{tabular}

NO from the baseline value at days 2 and 3 (median change (range): 4.2 (7.5) ppb, $\mathrm{p}=0.03$, and 3.0 (10.1) ppb, $\mathrm{p}=0.02$, respectively), whereas on the other hand, no significant changes in median exhaled NO could be detected in the placebo group at all study days as compared to baseline day 0 ( $>>0.4)$ (fig. 1). The changes in exhaled NO were significantly different between the RV16 and placebo group at days 2 and $3(\mathrm{p}<0.02)$.

\section{Relationship between NO levels and PC20 to histamine}

At baseline there was no correlation between NO levels and FEV1 $(\mathrm{p}=0.8)$, albeit that there was a significant inverse correlation between exhaled NO levels and PC20 (rank correlation coefficient $\left(r_{s}\right):-0.59, p=0.03$ ) (fig. 2). Hence, those patients with the lowest PC20 to histamine had the highest exhaled NO levels at baseline. The changes in exhaled NO levels did not correlate with changes in FEV 1 in both treatment groups ( $p>0.3$ ). However, in the RV16 group, the increase in exhaled NO levels at day 2

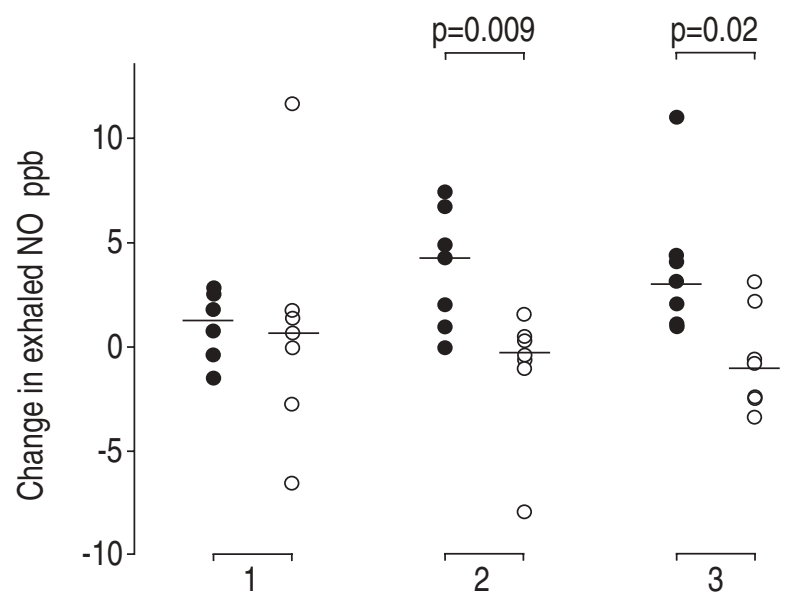

Day after infection

Fig. 1. - Individual changes in exhaled NO with corresponding median values (lines) at days 1, 2 and 3 after rhinovirus $16(\bullet)$ or placebo ( 0 ) inoculation.

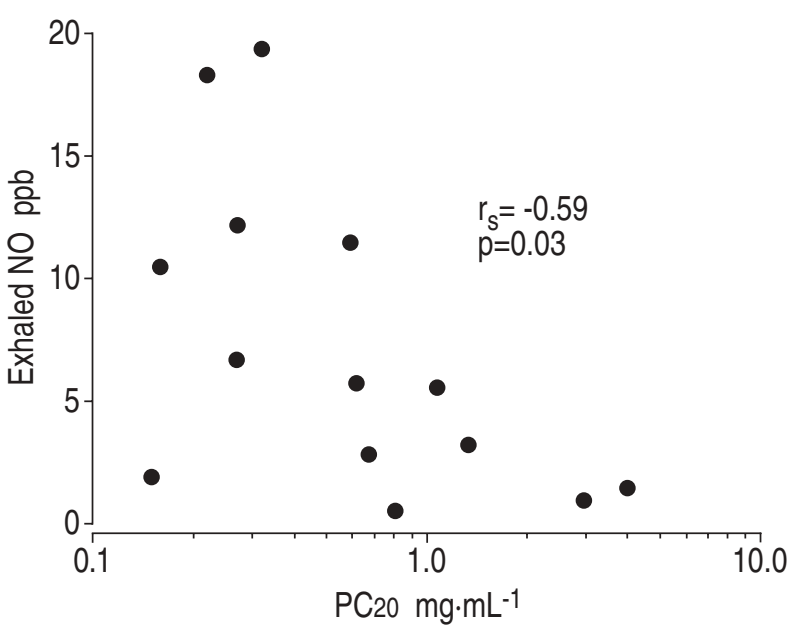

Fig. 2. - Relationship between exhaled NO and PC20 to histamine at baseline in 14 patients with asthma. $r_{s}$ : rank correlation coefficient. PC20: provocative concentration causing a $20 \%$ fall in forced expiratory volume in one second. 


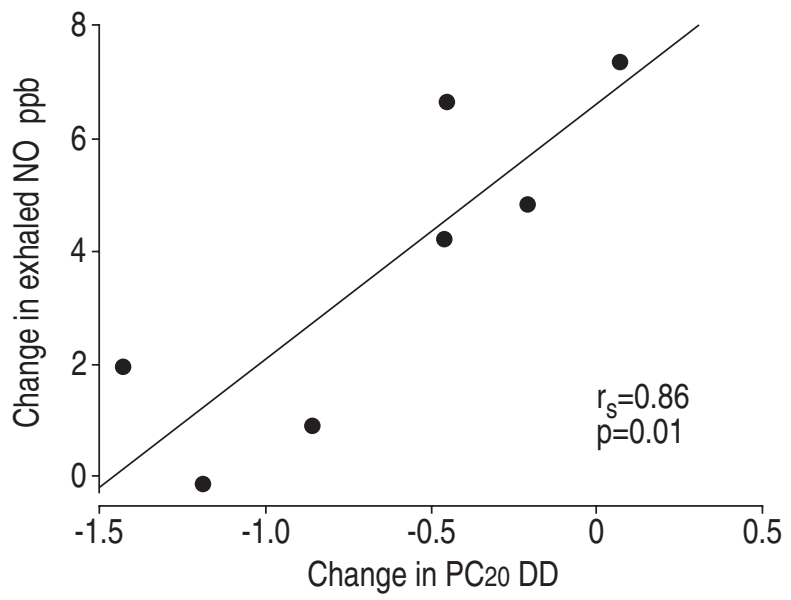

Fig. 3. - Relationship between change in PC20 to histamine (day 3 as compared to baseline) and change in exhaled NO levels (day 2 as compared to baseline) in the rhinovirus 16-infected subjects. The regression line has been drawn. DD: doubling doses. For further definitions, see legend to figure 2 .

was strongly and positively correlated with the decrease in PC20 to histamine at day $3\left(\mathrm{r}_{\mathrm{s}}: 0.86, \mathrm{p}=0.01\right)$, whilst there was a trend towards such a relationship for NO levels at day $3\left(\mathrm{r}_{\mathrm{s}}: 0.68, \mathrm{p}=0.09\right)$. Hence, those patients with the largest decrease in $\mathrm{PC} 20$ following virus infection exhibited the smallest increase in exhaled NO and vice versa (fig. 3).

\section{Discussion}

The results of the present study show that experimental RV16 infection increases exhaled NO levels in asthmatic subjects in vivo. Remarkably, the changes in exhaled NO levels after RV16 infection appear to be positively correlated to the changes in $\mathrm{PC} 20$ to histamine: the greater the increase in NO, the smaller the decrease in PC20. This suggests that endogenously produced NO within the airways can exert protective activity against rhinovirusinduced airway hyperresponsiveness in asthma.

This is the first study demonstrating changes in exhaled NO following respiratory virus infection in asthma. In a previous study by KHARITONov et al. [25], it has also been shown that exhaled NO increases following a spon-taneous, undefined upper respiratory tract infection of presumable viral origin in normal subjects in vivo. It is remarkable that, following RV-16 infection, the current changes in exhaled NO were positively associated with those in airway hyperresponsiveness, whereas a negative correlation was demonstrated between NO levels and PC20 at baseline. This underlines a potentially two-sided role of NO in chronic asthma and exacerbations of the disease. The presently observed changes in exhaled NO resemble those following allergen challenge [31], which is indicative of their involvement in inflammatory mechanisms.

The methodology of measuring exhaled NO has not yet been standardized among the various laboratories. However, we made several attempts to validate the measurements. NO was measured during a single breath by a calibrated chemiluminescence analyser. Firstly, to exclude possible differences in exhaled NO based on smok- ing and medication use, we selected a homogenous group of nonsmoking, atopic, mildly to moderately asthmatic patients not using any steroid medication prior to and during the experiments. Secondly, in order to maintain similar time-periods of NO production within the airways in and between individual subjects, the expiration time was standardized by normalizing the expiratory flow to the individual FVC $\left(0.05 \times \mathrm{FVC} \cdot \mathrm{s}^{-1}\right)$. One of the criticisms could be that we used ambient inspired air, which is not free of NO. Although it has been shown that high concentrations of inhaled NO have disappeared in exhaled air after $15 \mathrm{~s}$ of breathholding [9], an influence of environmental NO on exhaled NO levels cannot be fully excluded. However, by including a placebo group, in which exhaled NO remained stable, we could rule out a major influence of (changes in) ambient NO on our measurements.

How can the present observations be explained? It is likely that the increase in exhaled NO levels following RV16 infection is due to elevated iNOS activity, as opposed to cNOS activity. It has been shown that glucocorticoids, which inhibit the expression of iNOS, can reduce exhaled NO levels, favouring iNOS origin of increased exhaled NO levels in asthma [12]. Expression of iNOS has been demonstrated in human alveolar macrophages and epithelial cells $[32,33]$, and such epithelial expression may even be increased in subjects with asthma [33]. Induction of iNOS expression in respiratory epithelial cells potentially involves the transcription factor nuclear factor (NF)- $\mathrm{KB}$ [34], which may occur secondary to virusinduced cytokine release. Indeed, RV16 stimulation of human bronchoalveolar lavage (BAL) macrophages and blood monocytes in vitro increases the secretion of TNF$\alpha$ and IL-1 $\beta$ within $24 \mathrm{~h}$ [22], whilst IFN- $\gamma$ and/or IL-1 $\beta$ levels in nasal lavages of symptomatic subjects increased within $44 \mathrm{~h}$ of RV or corona virus inoculation [23, 24]. At present it is still unknown whether experimental rhinovirus infection induces proinflammatory cytokine release within the intrapulmonary airways. However, recent data in asthmatics using bronchial biopsies [20] or induced sputum [35] strongly indicate that this actually occurs. Hence, the increase in exhaled NO within 2 days after experimental RV16 infection in vivo might be due to induction of iNOS expression. Once iNOS expression is induced, production of NO may continue for days [15].

Elevated NO levels within the airways can be both deleterious and protective in asthma. In theory high concentrations of NO may have proinflammatory effects $[4,15]$. $\mathrm{NO}$ is a potent vasodilator and may increase plasma exudation within the airways. Additionally, toxic products formed by the reaction of NO with superoxide, such as peroxynitrite [15], can have cytotoxic effects contributing to the epithelial shedding in asthma [36]. Interestingly, high concentrations of NO may inactivate cNOS thereby reducing its relaxant effects [37]. Our finding of a positive correlation between exhaled NO levels and airway hyperresponsiveness at baseline suggests, but does not prove, proinflammatory activity of NO within the airways in asthma. On the contrary, the observation of a reverse correlation between the virus-induced changes in exhaled NO and airways hyperresponsiveness is suggestive of protective effects of increased NO synthesis following virus infection. This result is in keeping with previous observations in guinea-pigs by FoLKERTS et al. [26], 
suggesting that NO deficiency may be the underlying cause for the development of virus-induced airway hyperresponsiveness to histamine in vitro. These authors showed a marked reduction in the release of NO in tracheas of virus-infected guinea-pigs accompanied by an enhanced reactivity to histamine, whereas these effects could be prevented by the administration of the NOS substrate, L-arginine. NO has the capacity to relax airway smooth muscle through stimulation of guanylyl cyclase resulting in an increase in cyclic guanosine monophosphate (cGMP) which leads to a subsequent decrease in intracellular calcium [4]. It is unclear whether, endogenously, NO can exert such protective effects in vivo; NO derived from epithelial cells $[32,33]$ may not easily reach airway smooth muscle cells. This is supported by the observation that exogenous inhaled NO is only a weak bronchodilator, providing little protection against methacholine challenge in patients with asthma [38]. Hence, the precise mechanisms along which endogenous NO may exert its potentially beneficial properties in asthma remain to be established.

What are the clinical implications of our findings? Our results confirm the potential usage of exhaled nitric oxide as marker of disease activity during follow-up of patients with asthma, as appeared from studies using allergen challenge [31] or steroid therapy [12]. Apparently, exhaled nitric oxide can also be used to monitor virus-induced exacerbations in asthmatic subjects. This may be potentially relevant in view of the predominant role of viral respiratory tract infections in exacerbations of the disease $[17,18]$. It remains uncertain whether blockade or augmentation of nitric oxide synthesis will be beneficial in chronic asthma or during acute worsening of the disease. Hence, the explicit role of nitric oxide in asthma and during exacerbations should be examined using both specific (inducible) and nonspecific (both inducible and constitutive) inhibitors of nitric oxide syntheses in general and during viral respiratory tract infections in particular in subjects with asthma.

\section{References}

1. National Institutes of Health and National Heart, Lung, and Blood Institute. 1995. Global initiative for asthma: global strategy for asthma management and prevention NHLBI/WHO workshop report. NIH and NHLBI Publication No.(PHS)95-3659.

2. Djukanovic R, Roche WR, Wilson JW, et al. Mucosal inflammation in asthma. Am Rev Respir Dis 1990; 142: 434-457.

3. Barnes PJ, Liew FY. Nitric oxide and asthmatic inflammation. Immunol Today 1995; 16: 128-130.

4. Nijkamp FP, Folkerts G. Nitric oxide and bronchial reactivity. Clin Exp Allergy 1994; 24: 905-914.

5. Borland C, Cox Y, Higenbottam T. Measurement of exhaled nitric oxide in man. Thorax 1993; 48: 1160-1162.

6. Persson MG, Wiklund NP, Gustafsson LE. Endogenous nitric oxide in single exhalations and the change during exercise. Am Rev Respir Dis 1993; 148: 1210-1214.

7. Alving K, Weitzberg E, Lundberg JM. Increased amount of nitric oxide in exhaled air of asthmatics. Eur Respir $J$ 1993; 6: 1368-1370.

8. Persson MG, Zetterström O, Agrenius V, Ihre E, Gustafson LE. Single-breath nitric oxide measurements in asthmatic patients and smokers. Lancet 1994; 343: 146-
147.

9. Kharitonov SA, Yates D, Robbins RA, Logan-Sinclair R, Shinebourne EA, Barnes PJ. Increased nitric oxide in exhaled air of asthmatic patients. Lancet 1994; 343: 133-135.

10. Massaro AF, Mehta S, Lilly CM, Kobzik L, Reilly JJ, Drazen JM. Elevated nitric oxide concentrations in isolated lower airway gas of asthmatic subjects. Am J Respir Crit Care Med 1996; 153: 1510-1514.

11. Massaro AF, Gaston B, Kita D, Fanta C, Stamler JS, Drazen JM. Expired nitric oxide levels during treatment of acute asthma. Am J Respir Crit Care Med 1995; 152: 800-803.

12. Kharitonov SA, Yates DH, Barnes PJ. Inhaled glucocorticoids decrease nitric oxide in exhaled air of asthmatic subjects. Am J Respir Crit Care Med 1996; 153: 454-457.

13. Moncada S, Palmer RMJ, Higgs EA. Nitric oxide: physiology, pathophysiology, and pharmacology. Pharmacol Rev 1996; 43: 109-142.

14. Robbins RA, Barnes PJ, Springall DR, et al. Expression of inducible nitric oxide in human lung epithelial cells. Biochem Biophys Res Commun 1994; 203: 209-218.

15. Barnes PJ, Belvisi MG. Nitric oxide and lung disease. Thorax 1993; 48: 1034-1043.

16. Mannick JB. The antiviral role of nitric oxide. Res Immunol 1995; 146: 693-697.

17. Johnston SL, Pattemore PK, Sanderson G, et al. A community study of the role of virus infections in exacerbations of asthma in 9-11 year old children. Br Med J 1995; 310: $1225-1228$.

18. Nicholson KG, Kent J, Ireland DC. Respiratory virus and exacerbations of asthma in adults. Br Med J 1993; 307 : 982-986.

19. Cheung D, Dick EC, Timmers MC, De Klerk EPA, Spaan WJM, Sterk PJ. Rhinovirus inhalation causes long-lasting excessive airway narrowing in response to methacholine in asthmatic subjects in vivo. Am J Respir Crit Care Med 1995; 152: 1490-1496.

20. Fraenkel DJ, Bardin PG, Sanderson G, Lampe F, Johnston SL, Holgate ST. Lower airways inflammation during rhinovirus colds in normal and asthmatic subjects. Am J Respir Crit Care Med 1995; 151: 879-886.

21. Grünberg K, Timmers MC, Smits $\mathrm{HH}$, et al. Effect of experimental rhinovirus 16 colds on airway hyperresponsiveness to histamine and interleukin- 8 in nasal lavage in asthmatic subjects in vivo. Clin Exp Allergy 1997; 27: $36-45$.

22. Gern JE, Galagan DM, Dick EC, Busse WW. Rhinovirus stimulates monocytes and airway macrophages to produce IL- $1 \beta$ and TNF $\alpha$ protein and mRNA. Am J Respir Crit Care Med 1993; 149: A357.

23. Proud D, Gwaltney JM Jr, Hendley JO, Dinarello CAN, Gills S, Schleimer RP. Increased levels of interleukin-1 are detected in nasal secretions of volunteers during experimental rhinovirus colds. J Infect Dis 1994; 169: 1007-1013.

24. Linden M, Greiff L, Andersson M, et al. Nasal cytokines in common cold and allergic rhinitis. Clin Exp Allergy 1995; 25: 166-172.

25. Kharitonov SA, Yates D, Barnes PJ. Increased nitric oxide in exhaled air of normal human subjects with upper respiratory tract infections. Eur Respir J 1995; 8: 295297.

26. Folkerts G, Van der Linde HJ, Nijkamp FP. Virus-induced airway hyperresponsiveness in guinea-pigs is related to a deficiency in nitric oxide. J Clin Invest 1995; 95: 26-30.

27. Quanjer PH, Tammeling GJ, Cotes JE, Pedersen OF, Peslin R, Yernault J-C. Lung volumes and forced ventilatory 
flows. Eur Respir J 1993; 6 (Suppl. 16): 5-40.

28. Sterk PJ, Fabbri LM, Quanjer PH, et al. Standardized challenge testing with pharmacological, physical and sensitizing stimuli in adults. Eur Respir J 1993; 6 (Suppl. 16): 53-83.

29. Lemanske RF, Dick EC, Swenson CAN, Vrtis RF, Busse WW. Rhinovirus upper respiratory tract infection increases airway hyperreactivity and late asthmatic reactions. $J$ Clin Invest 1989; 83: 1-10.

30. Gwaltney JM Jr, Hendley O, Hayden FG, et al. Updated recommendations for safety-testing of viral inocula used in volunteer experiments on rhinovirus colds. In: Melnick JL, ed. Progress in Medical Virology. Volume 39. Basel, Karger, 1992; pp. 256-263.

31. Kharitonov SA, O'Connor BJ, Evans DJ, Barnes PJ. Allergen-induced late asthmatic reactions are associated with elevation of exhaled nitric oxide. Am J Respir Crit Care Med 1995; 151: 1894-1899.

32. Kobzik L, Bredt DS, Lowenstein CJ, et al. Nitric oxide synthase in human and rat lung: immunocytochemical and histochemical localization. Am J Respir Cell Mol Biol 1993; 9: 371-377.
33. Hamid Q, Springall DR, Riveros-Moreno V, et al. Induction of nitric oxide synthase in asthma. Lancet 1993; 342 : $1510-1513$.

34. Xie Q, Kashiwabara Y, Nathan C. Role of transcription factor NF- $\kappa \mathrm{B} / \mathrm{Rel}$ in induction of nitric oxide synthase. $J$ Biol Chem 1994; 269: 4705-4708.

35. Grünberg K, Smits HH, Timmers MC, et al. Experimental rhinovirus 16 infection. Effects of cell differentials and soluble markers in sputum in asthmatic subjects. Am J Respir Crit Care Med 1997; 156: 609-616.

36. Sadeghi-Hashjin G, Folkerts G, Henricks PAJ, et al. Peroxynitrite induces airway hyperresponsiveness in guinea pigs in vitro and in vivo. Am J Respir Crit Care Med 1996; 153: 1697-1701.

37. Griscavage JM, Hobbs AJ, Ignarro LJ. Nitric oxide: biochemistry, molecular biology, and therapeutic implications. In: Ignarro L, Murad F, eds. Advances in Pharmacology. Volume 34. San Diego, CA, Academic Press, 1995; pp. 215-234.

38. Högman M, Frostell CG, Hedenström H, Hedenstierna G. Inhalation of nitric oxide modulates adult human bronchial tone. Am Rev Respir Dis 1993; 148: 1474-1478. 